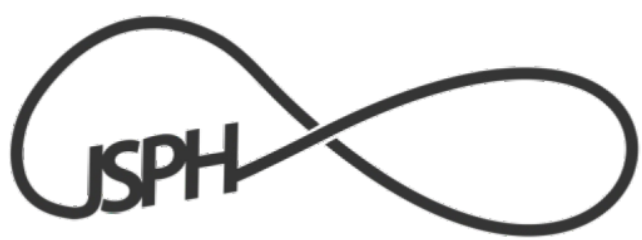

Jurnal Sosiologi Pendidikan Humanis

E-ISSN 2527-5879 P-ISSN 2527-5879

http://journal2.um.ac.id/index.php/jsph

Email: jsphum@yahoo.co.id

Volume 2, Nomor 1, Juli 2017

Halaman 16-22

\title{
KEARIFAN LOKAL MASYARAKAT ETNIS TOLAKI DALAM PENGELOLAAN SUMBER DAYA PESISIR DI KECAMATAN LALONGGASUMEETO KABUPATEN KONAWE PROVINSI SULTRA
}

\author{
Sulsalman Moita \\ Jurusan Sosiologi, Fakultas Ilmu Sosial dan Politik Universitas Halu Oleo \\ Email: moitasulsalman@yahoo.co.id
}

\begin{abstract}
Abstrak
Penelitian dengan lokus di Kecamatan Lalonggasumeeto Kabupaten Konawe Provinsi Sulawesi Tenggara, bertujuan untuk: (1) menganalisis pola pengelolaan sumber daya pesisir berbasis nilai-nilai kearifan lokal etnis Tolaki; (2) mengkaji perubahan nilai-nilai kearifan lokal sebagai dampak dari modernisasi dan kapitalisme; dan (3) menganalisis konsekuensi perubahan nilai-nilai kearifan lokal terhadap kebertahanan masyarakat sebagai sistem sosial. Metode penelitian ini adalah kualitatif dengan pendekatan studi kasus. Dalam pengumpulan data, peneliti bertindak sebagai instrumen penelitian. Teknik pengumpulan data dilakukan melalui wawancara mendalam, observasi dan dokumentasi. Data dianalisis secara kualitatif. Hasil penelitian menunjukkan: (1) Pola pengelolaan sumber daya pesisir yang berbasis pada nilai-nilai kearifan lokal etnis Tolaki seperti tradisi mondonduri, mepuka, meboso, mearano, dan melupai,; menjadi katup pengaman entitas ekosistem perairan dari eksploitasi yang berlebihan; (2) Dinamika dan perubahan nilai-nilai kearifan lokal dalam pengelolaan sumber daya perairan, menyasar pada kelompok-kelompok penangkap dan budi daya perikanan yang berorientasi pada akumulasi modal dan spirit kapitalisme. Mereka adalah jaringan nelayan yang berafiliasi dengan kelompok pemodal kuat sehingga mengabaikan realitas kearifan lokal; (3) konsekuensi perubahan nilai-nilai kearifan lokal, secara faktual tidak terjadi secara holistik, karena sistem pranata perikanan etnis lokal mampu menjaga kebertahanan sistem sosial masyarakat.
\end{abstract}

Kata Kunci: kearifan lokal; pengelolaan; tolaki; pesisir.

\section{LOCAL INDIGENOUS OF ETHNICAL PEOPLE TOLAKI IN MANAGEMENT COAL RESOURCES IN DISTRICT LALONGGASUMEETO KONAWE REGENCY SOUTHEAST SULAWESI PROVINCE}

\begin{abstract}
Research with locus in District Lalonggasumeeto Konawe Regency Southeast Sulawesi Province, aims to: (1) analyze the pattern of coastal resource management based on the values of local Tolaki ethnic wisdom; (2) examine changes in the values of local wisdom as a result of modernization and capitalism; and (3) to analyze the consequences of changing the values of local wisdom towards community resilience as a social system. This research method is qualitative with case study approach. In data collection, researchers act as research instruments. Data collection techniques are done through in-depth interviews, observation and documentation. Data were analyzed qualitatively. The results showed: (1) The pattern of coastal resource management based on the values of local Tolaki ethnic wisdom such as the tradition of mondonduri, mepuka, meboso, mearano, and melumpai; be the safety valve of the aquatic ecosystem entity from excessive exploitation; (2) The dynamics and changes in the values of local wisdom in the management of aquatic resources, targeting groups of catchers and aquaculture oriented to the accumulation of capital and spirit of capitalism. They are a network of fishermen affiliated with powerful groups of investors that ignore the reality of local wisdom; (3) the consequences of changing the values of local wisdom, factual does not occur holistically, because the system of local ethnic fishery institutions is able to maintain the resilience of the social system of society.
\end{abstract}

Keywords: local wisdom; management; tolaki; coastal. 


\section{LATAR BELAKANG}

Sumber daya pesisir yang dimiliki oleh Indonesia, membutuhkan pola pengelolaan yang tepat agar kelestarian potensi yang ada tetap terjaga untuk generasi mendatang. Faktanya, pola pengelolaan yang ada saat ini masih cenderung bersifat government based management, dimana otoritas dan dominasi pemerintah pusat memegang kontrol dari sumber daya yang ada. Model ini menempatkan pemerintah pusat sebagai pengambil keputusan tertinggi dan cenderung bersifat sentralistik, sementara setiap daerah memiliki pola pengelolaan sumber daya yang berbeda berdasarkan karakteristiknya. Dampaknya, peran komunitas lokal mulai tereduksi yang berujung pada pola pengelolaan yang tidak efisien, konflik kepentingan, dan degradasi sumber daya pesisir.

Mengacu pada Undang-Undang No 31/2004 Pasal 6 tentang Perikanan, menyebutkan bahwa pengelolaan perikanan untuk kepentingan penangkapan ikan dan pembudidayaan ikan harus mempertimbangkan hukum adat dan/atau kearifan lokal serta memperhatikan peran serta masyarakat didukung menjadi dasar konstitusi bagi pengelolaan berbasis kearifan lokal. Hal ini membuat pengelolaan sumber daya alam akan dilaksanakan mulai dari tingkat daerah sampai ke pusat dan akan mereduksi peran negara yang selama ini terlalu dominan.

Pada aspek yang lain, kearifan lokal merupakan hak-hak kepemilikan (property rights) yang tidak hanya diartikan sebagai penguasaan terhadap suatu kawasan, akan tetapi juga sebagai salah satu bentuk strategi dalam melindungi sumber daya dari kegiatan perikanan yang dapat merusak (destructive fishing) dan berlebihan dalam mengambil sumber daya (over exploited) (Wahyono, 2010). Praktek pengelolaan perikanan yang berbasis kearifan lokal tersebut terbukti mampu untuk menciptakan perikanan berkelanjutan, dari berbagai aspek seperti sosial ekonomi, ekologi, komunitas maupun kelembagaan.. Oleh karena itu, penting untuk melihat dampak pengelolaan berbasis kearifan lokal terhadap keberlanjutan sumber daya alam.

Proses pengembangan kawasan pesisir dan laut hendaknya disusun menggunakan bingkai pendekatan berupa integralistik yang sinergistik dan harmonis, dengan memperhatikan sistem nilai dan kelembagaan yang tumbuh dan berkembang dalam masyarakat serta sejalan dengan sumber-sumber potensi lokal. Keraf (2010), mengatakan bahwa kearifan lokal atau tradisional adalah semua bentuk pengetahuan, keyakinan, pemahaman, atau wawasan serta adat kebiasaan atau etika yang menuntun perilaku manusia dalam kehidupan di dalam komunitas ekologis.
Saat ini nilai-nilai kearifan lokal dalam pengelolaan sumberdaya pesisir, banyak mendapat tekanan faktor eksternal seperti modernisasi perikanan, akulturasi sosial budaya, heterogenitas penduduk, dan dampak strukutural yang lahir dari kebijakan pembangunan yang sebagian tidak berpihak pada kepentingan masyarakat tradisi. Salah satunya adalah wilayah Kecamatan Lalonggasumeeto Kabupaten Konawe sebagai lokus penelitian ini.

Kecamatan Lalonggasumeeto merupakan wilayah pemekaran dari Kecamatan Soropia, yang hampir seluruh desa-desanya berada di wilayah pesisir dan laut berbatasan langsung dengan laut Sulawesi yang menghubungkan Kabupaten Morowali Provinsi Sulawesi Tengah dan Kabupaten Konawe Kepulauan. Wilayah yang sangat dekat dengan pusat pemerintahan Provinsi Sulawesi Tenggara (Kota Kendari), didominasi oleh masyarakatnya yang bekerja sebagai nelayan dan petani.

Pentingnya nilai-nilai kearifan lokal dalam pengelolaan sumberdaya pesisir di wilayah ini, menjadi komitmen sebagian masyarakat karena tidah hanya berorientasi pada penghormatan tradisi leluhur masa lalu, namun menjadi katup pengaman bagi keberlangsungan sistem sosial. Masyarakat etnis Tolaki yang mayoritas mendiami wilayah ini menjadikan tradisi kalosara sebagai fokus yang menaungi semua produk budaya termasuk nilai-nilai kearifan lokal dalam pengelolaan wilayah pesisir.

Eksistensi nilai-nilai kearifan lokal dalam pengelolaan sumber daya alam termasuk lingkungan pesisir merupakan norma-norma yang terkait dengan pengetahuan, teknologi, kepercayaan, kelembagaan yang dipraktekan oleh suatu komunitas/masyarakat selama bertahun-tahun dalam mengelola sumberdaya alam yang ada (Kurniawati, 2011).

Kearifan lokal tersebut juga merupakan proses pemaknaan oleh suatu komunitas terhadap lingkungannya. Kearifan lokal juga bisa dikonsepsikan sebagai kebijaksanaan setempat (local wisdom) atau kecerdasan setempat (local genius), pandangan hidup, ilmu pengetahuan, dan berbagai strategi kehidupan yang berwujud aktivitas yang dilakukan oleh masyarakat setempat dalam menjawab berbagai masalah dalam memenuhi kebutuhan mereka (Adillah, 2013). Sedangkan Keraf (2010) Kearifan lokal juga disebut sebagai semua bentuk pengetahuan, keyakinan, pemahaman atau etika yang menuntun prilaku manusia dalam kehidupan didalam komunitas ekologis.

Pentingnya nilai-nilai kearifan lokal dalam pengelolaan sumber daya pesisir juga dapat disinergikan dengan penguatam modal sosial (social capital) masyarakat. Modal sosial 
menekankan kepada kebersamaan dan energi kelompok yang menjelaskan unsur-unsur seperti partisipasi dalam suatu jaringan (networking), relasi timbal balik (reciprocity), rasa saling percaya (mutual trust), norma sosial (social norms), nilai-nilai (values), serta tindakan yang proaktif. (Hasbullah, 2006).

Kolaborasi dan sinergi nilai-nilai kearifan lokal yang didukung dengan penguatan kapasitas modal sosial (social capital) ini menjadi energi positif bagi masyarakat lokal termasuk etnik Tolaki dalam pengelolaan sumber daya pesisir, di tengah pengaruh modernisasi dan perkembangan ilmu pengetahuan dan teknologi pada bidang perikanan yang dapat menganggu eksistensi dan kerapuhan budaya lokal sebagai suatu sistem sosial.

Berdasarkan penjelasan di atas, hal yang coba diketengahkan dalam tulisan ini adalah bagaimana pola pengelolaan sumber daya pesisir berbasis nilai-nilai kearifan lokal etnis Tolaki di Kecamatan Lalonggasumeeto. Selain itu juga akan dilihat pada sejauh mana perubahan nilainilai dari kearifan lokal dalam berbagai pengelolaan sumberdaya pesisir sebagai dampak dari modernisasi dan kapitalisme dan bagaimana konsekuensi perubahan nilai-nilai kearifan lokal dalam pengelolaan sumberdaya pesisir terhadap kebertahanan masyarakat sebagai sistem sosial.

\section{METODE PENELITIAN}

Penelitian ini menggunakan metode studi kasus dengan pendekatan kualitatif, yang menghasilkan data deskriptif berupa kata-kata tertulis maupun lisan dan perilaku dari orangorang ataupun masyarakat pada wilayah penelitian (lihat Bogdan dan Taylor atau Kirk dan Miller dalam Maleong, 2000).

Sumber data tersebut adalah: data primer dikumpulkan dari informan yang terdiri dari masyarakat pesisir, tokoh masyarakat, tokoh adat, tokoh pemerintah, dan investor perikanan, dengan pendekatan wawancara mendalam dan observasi. Sedangkan data sekunder berupa dokumen, literatur, dan publikasi dikumpulkan dari monografi desa, laporan, buletin, dan data statistik.

Selanjutnya analisis data yang digunakan adalah analisis kualitatif (studi kasus) dengan langkah-langkah: telaah data yang didapat dari berbagai sumber hasil wawancara, observasi dan dokumen; reduksi mengenai data informasi dengan membuat abstraksi sebagai rangkuman inti dari semua pernyataan sehingga tetap ada; susunan data dan informasi dalam satuan-satuan; kategorisasi data dan informasi; hasil pengecekan keabsahan data dan informasi, dengan cara mengkonfrimasikan kembali setiap data dan informasi yang diperoleh.

\section{HASILDAN PEMBAHASAN \\ Pola pengelolaan sumber daya pesisir berbasis nilai-nilai kearifan lokal etnis Tolaki}

Wilayah Kecamatan Lalonggasumeeto terletak di jazirah tenggara Provinsi Sulawesi Tenggara, yang sebagian masyarakatnya menggantungkan hidupnya dari pengelolaan sumber daya pesisir, seperti aktivitas penangkapan ikan, pengelolaan rumput laut, budidaya hasil perairan, transportasi, sektor parawisata, dan sebagainya.

Etnis Tolaki yang mendiami kecamatan ini adalah etnis lokal (pribumi) yang tersebar merata di seluruh desa-desa pesisir. Pola pengelolaan sumber daya pesisir, selain mengadopsi nilainilai modernisasi juga masih mempertahankan pola pengelolaan yang bersumber dari nilai-nilai kearifan lokal, antara lain: mondonduri, mepuka, meboso, mearano, dan melupai.

Mondoduri merupakan aktivitas memancing ikan dengan memanfaatkan rawa, sungai, dan laut. Aktivitas ini biasa dilakukan secara individu maupun kelompok-kelompok kecil dengan memanfaatkan waktu senggang atau libur ketika rutinitas pekerjaan sedang rehat. Biasanya warga memancing ikan pada sore hari atau hari Sabtu dan Minggu. Temuan penelitian mengungkapkan bahwa aktivitas mondonduri ini telah dimanfaatkan oleh sebagian warga dengan membuka jasa pemancingan dengan sistem sewa perjam. Bahkan tak jarang di sejumlah spot-spot pemancingan dilakukan lomba memancing dengan hadiah yang cukup menggiurkan, termasuk dimaanfaakan oleh sejumlah pihak untuk kepentingan sosial dan politik.

Mepuka adalah aktivitas mencari ikan dengan menggunakan pukat atau jaring yang biasanya dilakukan di rawa atau sungai sekitar pemukiman penduduk. Saat ini aktivitas mepuka telah memanfaatkan kawasan perairan laut dengan menggunakan pukat harimau, yang tidak hanya membinasakan ikan-ikan kecil dan hasil laut lainnya, namun juga melanggar hukum yang berdampak pada pemidanaan. Namun demikian, aktivitas mepuka dengan menggunakan pukat harimau, bagi sebagian tokoh masyarakat (toono motuo) adalah perbuatan tercela karena dapat menganggu atau mengurangi ekosistem sungai dan laut seperti ikan-ikan kecil sehingga berdampak pada persediaan ikan pada jangka panjang yang semakin berkurang.

Meboso merupakan pola budidaya hasil laut dengan menampung pada suatu wadah/tempat di sekitar rawa, laut, dan sungai. Tujuannya selain untuk menampung hasil-hasil tangkapan agar memiliki ukuran yang lebih besar, juga menjadi katup pengaman konsumsi penduduk di masa paceklik. Temuan penelitian menunjukkan bahwa aktivitas meboso dalam konteks budidaya 
telah digunakan oleh sebagian penduduk untuk membangun kolam besar sebagai sarana wisata perikanan dan aktivitas pemancingan. Aktivitas meboso yang terbuat dari bahan bambu dan batang/daun rumbia (sagu) masih tetap dipertahankan oleh sebagian masyarakat etnik Tolaki di tengah modernisasi perikanan dengan sistem penampungan yang lebih canggih.

Mearano adalah aktivitas penangkapan ikan dengan memanfaatkan rawa-rawa buatan manusia dan di musim hujan air yang tergenang. Masyarakat etnik Tolaki biasanya menggali lobang di sekitar lahan perladangan atau area persawahan untuk menampung air hujan. Air hujan selain berfungsi untuk mengairi sawah dan tanaman pertanian lainnya, juga digunakan untuk menampung ikan yang dipanen ketika musim paceklik tiba. Aktivitas mearano ini banyak dilakukan oleh kaum perempuan dengan mengundang rekan-rekannya dengan sistem bagi hasil kepada pemiliknya. Aktivitas ini mengelaborasi nilai kearifan lokal dalam konteks medulu/mepokoaso (berkumpul atau bersatu) bagi kaum perempuan, termasuk menjadi wahana bagi mereka untuk mengkomunikasikan aktivitas kekeluargaan dan masalah-masalah perempuan dalam spektrum yang lebih luas.

Melupai, merupakan tradisi atau kebiasaan turun temurun dengan memanfaatkan air sungai mengalir atau rawa ukuran besar guna meracuni ikan dengan menggunakan tuba dari akar-akar pohon yang mengandung racun. Aktivitas ini marak sekitar tahun 70-an hingga 90-an dan biasanya dijadikan wahana pertemuan saudara atau para kerabat sambil bergembira dan bercengkrama mencari/mengambil ikan. Namun seiring dengan pelarangan dan penegakan hukum yang cukup ketat, aktivitas molupai ini sudah jarang dilakukan terutama kawasan-kawasan aliran sungai yang berhubungan langsung dengan kawasan irigasi penduduk.

Temuan penelitian ini mengungkapkan di sejumlah desa-desa pesisir di Kecamatan Lalonggasumeeto, tak jarang masih melakukan aktivitas molupai secara bersama-sama yang secara informal diketahui oleh pemerintah setempat (Kepala Desa dan Camat), yang tujuannya selain mendapatkan ikan untuk konsumsi keluarga juga sebagai wahana komunikasi serta kebersamaan warga sebagai suatu sistem sosial.

Perubahan nilai-nilai kearifan lokal dalam pengelolaan sumber daya pesisir sebagai dampak dari modernisasi dan kapitalisme

Modernisasi perikanan telah mengubah kultur dan perilaku manusia dalam memanfaatkan sumber daya pesisir, dari pola tradisional berubah menjadi pola modern. Perubahan ini dipengaruhi oleh sejumlah faktor seperti: modernisasi perikanan, perkembangan Iptek, heterogenitas masyarakat, dan kebijakan pemerintah yang dapat mempengaruhi sistem pranata sosial masyarakat pesisir.

Modernisasi perikanan merupakan bentuk pengejawatahan revolusi biru sebagian bagian yang tidak terpisahkan dengan revolusi hijau di hasil bidang agraris. Masyarakat pesisir atau nelayan di masa lalu adalah masyarakat yang subsisten dengan karakteristik masyarakatnya yang miskin dan dibawah standar kesejahteraan. Kondisi yang sama dialami oleh masyarakat Kecamatan Lalonggasumeeto (dulu Kecamatan Soropia). Pada temuan Tarimana (1995) mengungkapkan masyarakat etnik tolaki yang bermata pencaharian sebagai nelayan di wilayahwilayah pesisir, hanya mengandalkan aktivitas penangkapan ikan dengan perahu tanpa mesin (obangga, onia), aktivitas memancing biasa (mondoduri), dan menggunakan pukat biasa (mepuka) dengan hasil tangkapan hanya untuk konsumsi keluarga dan sekali-sekali barter dengan petani untuk ditukar dengan beras, sayur, ubi,jagung, dan buah-buahan.

Modernisasi perikanan yang ditandai dengan masuknya investor perikanan yang sebagian besar adalah etnis Tionghoa dengan memiliki kapal penangkap ikan bermesin, telah mengubah aktivitas warga lokal dari nelayan tradisional menjadi nelayan buruh yang menjadikan investor menjadi majikan dalam konteks patron-klien. Dengan sistem upah dan bagi hasil, masyarakat pesisir relatif menerima sistem itu karena tidak hanya penghasilan meningkat secara signifikan, tetapi membuka jaringan penangkapan yang lebih luas termasuk penguasaan teknologi perikanan. Temuan penelitian mengungkapkan, dampak dari modernisasi perikanan telah memunculkan investor-investor baru dari etnik lokal walaupun masih dalam jumlah yang kecil.

Perkembangan Iptek dalam spektrum perubahan sosial merupakan realitas yang tak terelakkan, karena proses adaptasi manusia yang relatif mudah untuk diterima juga memberi dampak positif bagi kehidupannya. Sejumlah indikator perkembangan Iptek dalam aktivitas perikanan/perairan seperti penggunaan perahu bermesin, penggunaan rumpon, budidaya teripang, budidaya rumput laut, transportasi perikanan, perkembangan parawisata; menjadi dampak positif perkembangan struktur sosial masyarakat pesisir yang lebih baik.

Temuan penelitian mengungkapkan nilainilai kearifan lokal masyarakat pesisir dalam pengelolaan sumber daya, semakin jarang dilakukan karena proses adaptasi terhadap Iptek berlangsung secara cepat. Masyarakat di wilayah ini tidak hanya mengandalkan aktivitas 
penangkapan ikan semata untuk memenuhi kebutuhan ekonomi keluarga, namun sebagian memiliki alat transportasi untuk distribusi barang dan manusia di pulau-pulau kecil terdekat seperti P.Bokori, Pulau Saponda, Pulau Hari. Selanjutnya masyarakat yang bermukim di sekitar Desa Watunggarandu, memanfaatkan pantai batugong untuk membangun villa, rumah makan, warung, dan gazebo untuk keperluan para wisatawan yang pengunjungnya umumnya berasal dari Kota Kendari, Kabupaten Konawe Selatan dan Kabupaten Konawe. Dalam konteks budidaya, sebagian masyarakat telah mengembangkan empang (tambak) untuk budidaya ikan bandeng (ikan bolu), budidaya rumput laut dan teripang, proses pengolahan ikan hasil tangkapan melalui pengasinan, pengasapan, pengeringan, dan pembuatan pakan ternak.

Heterogenitas masyarakat di wilayah pesisir dapat mendorong percepatan akulturasi dan asimilasi budaya termasuk dalam bidang ekonomi. Kehadiran pendatang dari berbagai latarbelakang etnis tidak hanya membuka networking (jaringan) baru dalam bidang ekonomi akan tetapi terjadinya akumulasi pengetahuan masyarakat lokal terhadap ide-ide dan kreativitas baru, termasuk mengubah kebiasaan lama yang tidak sesuai dengan iklim modernisasi.

Nilai-nilai kearifan lokal masyarakat dalam pengelolaan sumberdaya pesisir, kendatipun tidak bertentangan dengan nilai-nilai modenisasi, namun faktanya masyarakatnya dalam kondisi subsisten dan memenuhi kebutuhannya secara self suficient. Artinya, warga tidak memiliki kemampuan untuk menabung, investasi, dan merubah kondisi sosial ekonomi secara siginifikan.

Temuan penelitian mengungkapkan, kehadiran pendatang dari daerah lain seperti suku Bugis, Makassar, Jawa, Buton, Muna, dan etnis Tionghoa,telah meningkatkan kehidupan sosial ekonomi masyarakat lokal secara gradual. Hal ini dapat dilihat dari tingkat pendapatan, kondisi rumah, investasi, tabungan, pendidikan keluarga, pemenuhan kesehatan, dan sebagainya. Seluruh aspek perubahan kehidupan tersebut, tercipta dari relasi sosial termasuk membangun modal sosial yang bersifat bridging (menjembatani), antara masyarakat etnik lokal (Tolaki) dan masyarakat pendatang.

Kebijakan pemerintah dalam pembangunan masyarakat pesisir adalah mengandung pesan untuk keadilan dan kesejahteraan sosial, yang umumnya masih terperangkap dalam perangkap kemiskinan. Di masa lalu terdapat kebijakan restelment penduduk daerah pesisir dengan memindahkan mereka ke wilayah daratan untuk mengubah aktivitas dari nelayan menjadi petani. Wilayah Kecamatan Lalonggasumeeto (dulu Kecamatan Soropia) merupakan lokasi restelment penduduk di akhir tahun 80 -an. Namun masyarakat yang menerima program tersebut selama kurang lebih dua tahun hanya memanfaatkan alokasi jatah rumah, lahan, dan konsumsi dari pemerintah, namun ketika jatah habis mereka (nelayan) kembali beraktivitas sebagai nelayan.

Saat ini intervensi pemerintah terhadap masyarakat pesisir lebih pada proses pemberdayaan. Sejumlah program seperti PNPM, Program andalan Pemerintah Provinsi (Bahteraemas), dan Program andalan Pemerintah Kabupaten Konawe (Perisai), banyak menyasar komunitas masyarakat pesisir dengan bantuan perahu bermotor, kredit nelayan, koperasi nelayan, pelatihan dan skill masyarakat pesisir, dan sebagainya. Komitmen pemberdayaan bagi masyarakat pesisir oleh Pemerintah di Kecamatan Lalonggasumeeto, dalam faktanya telah mendorong peningkatan sosial ekonomi masyarakat, termasuk perubahan paradigma berpikir, kebiasaan, dan sikap dalam pengelolaan sumberdaya pesisir yang ada.

\section{Konsekuensi perubahan nilai-nilai kearifan lokal terhadap kebertahanan masyarakat sebagai suatu sistem sosial.}

Dalam konteks pengelolaan dan pemanfaatan pada sumberdaya pesisir yang lestari serta berkelanjutan peranan lembaga lokal beserta kearifan lokal, tradisi dan budaya setempat memiliki peluang yang cukup strategis untuk dimanfaatkan dalam upaya pembinaan terhadap masyarakat. Aspek ini dapat dijadikan sebagai jembatan penghubung yang menghubungkan antara program yang akan diterapkan otoritas pemerintah dengan apa yang telah menjadi kebutuhan masyarakat. Sehingga diharapkan apapun target kelestarian lingkungan dan kesejahteraan masyarakat yang direncanakan pemerintah diyakini akan dapat berjalan dengan cepat dan tepat sasaran sehingga memberikan dampak yang positif terhadap keberhasilan dan keberlanjutan kelestarian perikanan.

Pada aspek yang lain seperti pengelolaan dan pemanfaatan sumberdaya yang ada di pesisir tersebut dapat mengubah kebiasaan masyarakat dari ketaatan terhadap nilai-nilai kearifan lokal berubah melalui adaptasi nilai-nilai modernisasi. Kondisi yang sama dialami oleh masyarakat etnik Tolaki yang berada di Kabupaten Konawe, yang menjadikan modernisasi perikanan sebagai meliu untuk transformasi atas pengetahuan, pandangan, sikap, kebiasaan, perilaku, dan aktivitas pesisisir yang lebih inovatif dan sejahtera.

Perubahan sikap dan perilaku masyarakat ini 
dalam pengelolaan sumberdaya pesisir merupakan konsekuensi logis dari kemampuan membangun relasi dan jaringan sosial baik secara internal maupun secara eksternal. Secara internal, terdapat kesepahaman dan komitmen seluruh stakeholder mulai dari tokoh pemerintah, tokoh masyarakat, tokoh agama, nelayan, tokoh pemuda; dan sebagainya untuk mereduksi kebiasaan-kebiasaan lama dalam aktvitas kemaritiman yang tidak fungsional dan tidak produktif, seperti upacara petik laut, pemberian sesajen, menangkap ikan dengan meracuni, dan sebagainya.

Sedangkan secara eksternal, dilandasi oleh sikap keterbukaan untuk menerima perubahan, Iptek, akulturasi dan asimilasi budaya, serta intervensi pemerintah yang semuanya berdimensi pemberdayaan. Masyarakat lokal mesti menghilangkan sikap apriori terhadap perubahan dari luar karena nilai-nilai yang dibawa tidak bertujuan untuk mereduksi nilai-nilai lama, namun memperbaikinya untuk perubahan dan inovasi baru. Faktanya, perkembangan kehidupan sosial ekonomi, meningkatnya sektor parawisata, terbukanya jaringan antarnelayan, koperasi nelayan, transportasi antarpulau merupakan indikator manfaat faktor eksternal dalam konteks keberdayaan masyarakat pesisir.

Dimensi fakor internal dan faktor eksternal secara makro memang telah mengubah kebiasaan dan aktivitas masyarakat etnik lokal dalam pengelolaan sumber daya pesisir. Namun demikian nilai-nilai kearifan lokal dalam aktivitas penangkapan dan budidaya seperti mondoduri, mepuka, meboso, melupai, dan mearano masih tetap dipertahankan sebagai bentuk simbolisasi dan penghormatan entitas budaya masyarakat Tolaki sebagai sistem sosial. Penghormatan nilainilai tersebut, berkorelasi dengan kuatnya ikatan modal sosial masyarakat seperti simbol kalosara yang berwujud pada aktivitas bersama seperti molupai, simbol medulu/mepokoaso (bersatu) dalam aktivitas mondodouri, simbol teporombu (berkumpul) dalam aktivitas mearano, dan sebagainya.

\section{KESIMPULAN}

Pola pengelolaan sumberdaya pesisir berbasis nilai-nilai kearifan lokal etnis Tolaki, secara kuantitas telah mereduksi kebiasaan masyarakat yang dimasa lalu menjadi katup pengaman dalam memenuhi kebutuhan sosial ekonomi. Namun, demikian aktivitas penangkapan dan budidaya perairan, seperti mondoduri, meboso, melupai, mearano, dan mepuka menjadi kebiasaan yang tetap dipertahankan untuk keberlangsungan tatanan sistem sosial dan mewarisi tradisi budaya masa lalu.
Perubahan nilai-nilai kearifan lokal dalam pengelolaan sumber daya pesisir sebagai dampak dari modernisasi dan kapitalisme merupakan dampak dari faktor modernisasi perikanan, perkembangan ilmu pengetahuan dan teknologi, heterogenitas masyarakat, dan kebijakan pemerintah. Faktor-faktor tersebut selain mengubah sikap, pandangan, pengetahuan, dan aktivitas masyarakat dalam pengelolaan sumberdaya pesisir, juga dapat meningkakan kesejahteraan dan pemenuhan kebutuhan sosial ekonomi.

Konsekuensi perubahan nilai-nilai kearifan lokal terhadap kebertahanan masyarakat sebagai suatu sistem sosial menjadikan elemen modal sosial seperti jaringan, sikap saling percaya, nilai dan norma sosial, relasi timbal balik sebagai katup pengaman dari realitas perubahan terutama dari faktor eksternal seperti modernisasi perikanan, perkembangan ilmu pengetahuan dan teknologi, serta akulturasi sosial ekonomi dengan warga pendatang. Masyarakat etnis Tolaki menjadikan simbol kalosara, nilai-nilai medulu/mepokoaso, nilai teporombu sebagai sistem simbol keberlangsungan aktivitas penangkapan/budidaya dalam dimensi kearifan lokal walaupun secara kuantitas aktivitasnya semakin berkurang.

\section{DAFTAR RUJUKAN}

Adillah, Giska. (2013). Enhacing Local Wisdom Through Local Content of Elementary School in Java, Indonesia. Proceeding of the Global Summit on Education 2013 (e-ISBN 978-967-11768-01)11-12 March 2013, Kuala Lumpur.

Hasbullah, J. (2006). Social capital: Menuju Keunggulan Budaya Manusia Indonesia. Jakarta: MR-United Press.

Ibad, Syahrul. (2017). Kearifan lokal Pemberdayaan Masyarakat dalam Pengelolaan dan Pembangunan Sumberdaya Perikanan yang Berkelanjutan (Studi Kabupaten Situbondo). Jurnal ilmu Perikanan Volume 8, No. 1 April 2017.

Keraf, A.S. (2010). Etika Lingkungan Hidup. Jakarta: Buku Kompas.

Kurniwati, Nendah dan Reswati Elly. (2011). Kearifan Lokal Masyarakat Lamalera: Sebuah ekspresi hubungan manusia dengan laut. Buletin Riset Sosek Kelautan dan Perikanan Vol 6 No.2 2011.

Moleong, L.J. (2010). Metodologi Penelitian Kualitatif. Bandung: Remaja Rosda Karya

Satria, Arif. (2002). Sosiologi Masyarakat Pesisir. Jakarta: PT Pustaka Cidesindo.

Sugiyono, (2011). Metode Penelitian Kuantitatif Kualitatif dan $R \& D$. Bandung: Alfabeta. 
Jurnal Sosiologi Pendidikan Humanis Volume 2, Nomor 1, Juli 2017

Tarimana, Abdurrauf. (1995). Kalosara sebagai Fokus Kebudayaan Suku Tolaki. Jakarta: Rineka Cipta.

Undang-Undang No 31/2004 tentang Perikanan Wahyono, (2010). Pemberdayaan Masyarakat Nelayan. Yogyakarta: Media Presindo. 